Original Research Article

\title{
Impact of educational session on knowledge and attitude towards teratogenicity among undergraduate medical students: a comparative study
}

\author{
Priyanka Kumari $^{1 *}$, Vasundara Krishnaiah ${ }^{1}$, Girish Kumaraswamy ${ }^{1}$, Tushar J. Tamboli ${ }^{2}$
}

${ }^{1}$ Department of Pharmacology, Kempegowda Institute of Medical Sciences, Bangalore, Karnataka, India

${ }^{2}$ Medical Services Specialist, Accenture services Pvt Ltd, Bangalore, Karnataka, India

Received: 28 August 2017

Revised: 11 September 2017

Accepted: 25 September 2017

*Correspondence to:

Dr. Priyanka Kumari,

Email: priyanka.jha.81@ gmail.com

Copyright: (C) the author(s), publisher and licensee Medip Academy. This is an openaccess article distributed under the terms of the Creative Commons Attribution NonCommercial License, which permits unrestricted noncommercial use, distribution, and reproduction in any medium, provided the original work is properly cited.

\begin{abstract}
Background: Teratogenicity is a major cause of abortion, still birth and can result in longterm disability with a significant impact on individuals, families, societies and healthcare systems. Drugs being one of the causes of teratogenicity, creating awareness among medical students, the future prescribing physicians, the rate of teratogenicity can be decreased. The objective was to compare the attitude and knowledge about teratogenicity among the medical undergraduates before and after an educational session on teratogenicity.

Methods: A pre-validated semi structured questionnaire on attitude and knowledge about teratogenicity was distributed to $2^{\text {nd }}$ year medical students (147) before and after teratogenicity educational session. Results obtained were compared within the group. Paired $t$ test was used for within the group comparison. P-Value $<0.05$ was considered to be statistically significant.

Results: Improvement in knowledge showed statistically significant improvement following teratogenicity educational session (P-Value=0.0003). Improvement was there in post session attitude scores as well, however, it was not significant ( $\mathrm{P}-$ Value $=0.64)$.

Conclusions: Early reinforcement about teratogenicity in medical students enables them to decide appropriate drug therapy while prescribing for females of reproductive age group.
\end{abstract}

Keywords: Knowledge, Teratogenicity, Undergraduate medical students

\section{INTRODUCTION}

Teratogenicity is defined as "any morphological, behavioral or biochemical effect induced during embryonic life or fetal life detected at birth or later". ${ }^{1,2}$ The term teratogen is originated from a Greek word 'teras' meaning a monster. ${ }^{1}$ A number of factors like infections $(\mathrm{TORCH})$, ionizing radiation, metabolic disturbances (diabetes mellitus and phenylketonuria) and drugs act like a teratogen. ${ }^{3}$ Teratogenicity is a major cause of abortion, still birth and can result in longterm disability with a significant impact on individuals, families, societies, and healthcare systems. ${ }^{4}$

WHO had estimated 2,70,000 deaths during the first 28 days of life to be due to congenital anomalies globally. March of Dimes (MOD) global report on birth defects stated 7.9 million births $(0.6 \%$ of total births) to be associated with serious birth defects annually. Majority $(94 \%)$ of these defects occur in middle and low income countries. Joint WHO and MOD meeting reported birth defect to account for $7 \%$ of all neonatal mortality and 3.3 million under five deaths. Common birth defects include 
congenital heart disease, congenital deafness and neural tube defect. ${ }^{5}$

India being a high birth rate country the annual birth defect prevalence of $6-7 \%$ can significantly affect many health indicators. ${ }^{5,6}$ Teratogenicity is an important cause of fetal birth defect leading to neonatal morbidity and mortality still awareness about teratogenicity is found to be inadequate among physicians. ${ }^{7,8}$ Teratogenic drugs are responsible for $<1 \%$ of birth defects. ${ }^{9}$ Previous studies had reported only $24 \%$ of physicians to be confident while prescribing for a pregnant woman. ${ }^{10}$ During pregnancy $59 \%$ of women are prescribed with drugs other than vitamin and mineral supplements. ${ }^{9}$ Category D drugs were used in $0.41 \%$ to $23 \%$ and category $\mathrm{X}$ drugs were used in 0 to $2.9 \%$ of the cases during pregnancy. ${ }^{7,11}$

There is a need for the early exposure of students to the concept of teratogenicity which will bridge the gap in their knowledge as well as which will lay the foundation for safe prescribing for a pregnant woman. Thus, creating awareness through early educational intervention among undergraduate medical students, the future physicians, is necessary to decrease the incidence of preventable teratogenicity. Hence the present study is taken up.

The objective of this study was to compare the knowledge and attitude towards teratogenicity among undergraduates before and after an educational session on teratogenicity.

\section{METHODS}

This was a questionnaire based comparative study carried out at Kempegowda Institute of Medical Sciences (KIMS), Bangalore over a period of 3 months from $15^{\text {th }}$ January 2017 to $15^{\text {th }}$ April 2017. The inclusion criteria were (i) second year MBBS students (ii) students studying at KIMS. The exclusion criteria were (i) students not willing to participate in the study (ii) dental and physiotherapy students. With prior approval from Institutional Ethics Committee, a pre-validated semi-structured questionnaire comprising of questions on knowledge and attitude towards teratogenicity was used as a tool. This questionnaire was divided in 3 sections. Section 1 had questions on the demographic details of the students: age and gender. Section 2 assessed the participant's knowledge by using a set of semi-structured questions and the results were expressed as percentages. Section 3 of the questionnaire assessed the student's attitude towards teratogenicity and the results were expressed as percentages. After obtaining informed consent the questionnaire was distributed among the participating students and the response was obtained. The assessment of their performance was based on the scores $(0=$ wrong response and $1=$ correct response). This was followed by an educational session with power point presentation. The topic comprised of various aspects of teratogenicity including its causative factors, vulnerable period, outcome and category of teratogenic drugs. Later post-lecture response to the same questionnaire was taken from the participants. The results were analyzed and compared using paired t-test $(\mathrm{P}<0.05$ was considered significant). Descriptive statistics was used wherever required.

\section{RESULTS}

A total of 147 second year MBBS undergraduate students participated in the study. The response rate was $100 \%$.

Table 1: Demographic characteristics of subjects.

\begin{tabular}{|llll|}
\hline Total & Age (in years) $*$ & \multicolumn{2}{c|}{ Gender } \\
\hline & & Female $(\%)$ & Male (\%) \\
\hline 147 & $19.93 \pm 0.78$ & $84(57.14)$ & $63(42.86)$ \\
\hline
\end{tabular}

*Age in years is expressed as mean $\pm \mathrm{SD}$.

Table 1 shows the demographic data of the students who participated in the study. Majority of the students were female. Mean age of the participating students was 19.93 years.

Table 2: Knowledge and attitude towards teratogenicity.

\begin{tabular}{|ll|}
\hline Questions & $\begin{array}{l}\text { Number of correct } \\
\text { response* } \%)\end{array}$ \\
\hline $\begin{array}{l}\text { Are you aware of the term } \\
\text { teratogenicity }\end{array}$ & $147(100)$ \\
\hline What are the causes of teratogenicity & $99(67.35)$ \\
\hline $\begin{array}{l}\text { Do you think all the drugs are safe } \\
\text { during pregnancy }\end{array}$ & $146(99.32)$ \\
\hline $\begin{array}{l}\text { Teratogenicity due to drugs can occur } \\
\text { during all the trimesters }\end{array}$ & $86(58.5)$ \\
\hline $\begin{array}{l}\text { What are the results/outcomes of } \\
\text { teratogenicity }\end{array}$ & $116(78.91)$ \\
\hline $\begin{array}{l}\text { Do you think teratogenic defects can } \\
\text { be diagnosed during pregnancy }\end{array}$ & $121(82.31)$ \\
\hline $\begin{array}{l}\text { Do you think teratogenic defect has } \\
\text { to be present at birth }\end{array}$ & $82(55.78)$ \\
\hline $\begin{array}{l}\text { Are you aware of US-FDA fetal risk } \\
\text { categories }\end{array}$ & $51(34.69)$ \\
\hline Definition of category A drugs & $93(63.27)$ \\
\hline Definition of category X drugs & $101(68.71)$ \\
\hline 1 st known drug teratogen & $40(27.21)$ \\
\hline Name of any two teratogenic drugs & $36(24.49)$ \\
\hline $\begin{array}{l}\text { Name of two teratogenic defects } \\
\text { associated with drugs }\end{array}$ & $20(13.61)$ \\
\hline $\begin{array}{l}\text { Do you think folic acid can prevent } \\
\text { neural tube defect }\end{array}$ & $136(92.52)$ \\
\hline Pre-session response & \\
\hline
\end{tabular}

*Pre-session response

Table 2 summarizes the pre-session knowledge and attitude scores of medical students on various aspects of teratogenicity. All of the students were aware of the term teratogenicity. Most of the students $(67.35 \%)$ had the knowledge of all the causes of teratogenicity. Majority of the participants $(99.32 \%)$ believed all the drugs are not safe during pregnancy. Only $58.5 \%$ were aware that drugs can act as a teratogen throughout the pregnancy. Various 
outcomes of teratogenicity were known to most of the (78.91\%) of the participants. Only $34.69 \%$ were aware of 'US-FDA fetal risk categories' though $63.27 \%$ and $68.71 \%$ of the participants chose correct response for category A and category X drugs respectively. Majority of them $(82.31 \%)$ believed that a teratogenic defect can be diagnosed during the pregnancy. Most of the participants $(55.78 \%)$ had the perception that the defect has to be present in the newborn at the time of the birth. Only $27.21 \%$ were aware that 'thalidomide' is the first known drug teratogen. Majority of the students $(75.51 \%)$ did not know the name of any two teratogenic drugs and $86.39 \%$ were unable to name any two drugs associated teratogenic defects. However majority of the students (92.52\%) believed that maternal folic acid supplementation can prevent neural tube defect in the fetus.

\section{Table 3: Comparison of mean pre-session and post- session knowledge score.}

\begin{tabular}{|lcccc|}
\hline Parameter & $\begin{array}{c}\text { Pre-session } \\
(\text { mean } \pm \text { SD })\end{array}$ & $\begin{array}{l}\text { Post-session } \\
(\text { mean } \pm \text { SD })\end{array}$ & $t$ & $\begin{array}{l}\text { p- } \\
\text { Value* }\end{array}$ \\
\hline $\begin{array}{l}\text { Knowledge } \\
\text { score }\end{array}$ & $5.37 \pm 2.126$ & $8.44 \pm 1.869$ & 5.68 & 0.0003 \\
\hline
\end{tabular}

*p-value statistically significant at $<0.05$

Table 3 shows the comparison between the pre-session and post-session scores for the knowledge about teratogenicity among the students. The mean value of 8.44 in the postsession group was higher than that in the pre-session group (5.37). The improvement in the knowledge score of postsession group was statistically significant (PValue $=0.0003$ ).

Table 4: Comparison of mean pre-session and postsession attitude score.

\begin{tabular}{|lllll|}
\hline Parameter & $\begin{array}{l}\text { Pre-session } \\
(\text { mean } \pm \text { SD })\end{array}$ & $\begin{array}{l}\text { Post-session } \\
(\text { mean } \pm \text { SD })\end{array}$ & $t$ & $\begin{array}{l}\text { P- } \\
\text { Value* }\end{array}$ \\
\hline $\begin{array}{l}\text { Attitude } \\
\text { score }\end{array}$ & $3.30 \pm 0.953$ & $3.61 \pm 0.735$ & 2.09 & 0.64 \\
\hline
\end{tabular}

*p-value statistically significant at $<0.05$

Table 4 shows the comparison of pre-session and postsession attitude scores among the students. The mean value of attitude score was higher in the post-session group (3.61) as compared to the pre-session group (3.30). However, this improvement in the attitude scores during post-session was not statistically significant (P-Value $=0.64)$.

\section{DISCUSSION}

Considering the burden which a teratogenic defect can bring to the patients, their family and the preventable nature of these defects, awareness regarding teratogenicity among the medical students is necessary. ${ }^{12}$

In our study, all of the students who were approached to participate in the study gave their consent for participation and majority of the participants were female. The response rate of $100 \%$ was suggestive of students' willingness to acquire the knowledge about teratogenicity. Similar results were seen in previous studies done among the undergraduate medical students. ${ }^{13,14}$

Most of the participants were aware of the multifactorial causation of the teratogenicity. Majority had the knowledge that a teratogenic defect can lead to various morbidity as well as mortality in the fetus/newborn. Most of the students thought that these defects can be diagnosed during the pregnancy. However the belief that the defects in the newborn have to be present at the time of birth, which was more prevalent among the participants, was wrong.

Though most of our study subjects believed that all drugs are not safe during pregnancy, lesser number of them was aware that a drug can be teratogenic throughout the pregnancy. A total of $63.27 \%$ and $68.71 \%$ of the participants chose correct answer for the definition of category $\mathrm{A}$ and category $\mathrm{X}$ drugs respectively however only $34.69 \%$ were aware of complete US-FDA fetal risk categories. Only $27.21 \%$ mentioned thalidomide as the first known drug teratogen in the human beings. Most of the students did not know the names of any two teratogenic drugs and even higher number of them did not know any two associated defects.

However, majority believed that maternal folic acid supplementation can prevent fetal neural tube defect. The knowledge regarding teratogenic drugs was inadequate. The results were similar to previous studies done among the physicians..$^{710,15}$

To the best of our knowledge similar studies among second year medical students have not been done previously.

When compared to the pre-session score there was a significant improvement in the post-session knowledge scores indicating the impact of educational session and scope for improvement with the early intervention among the students. ${ }^{16}$

The limitations of our study were that of small sample size of students of same academic year of a single institution. There was only one educational session. Long term impact of educational session was not measured. In future, further studies can be done with large sample size with subjects representing different education level assessing both immediate as well as long term impact.

\section{CONCLUSION}

Post-session improvement in knowledge score emphasizes the need for early exposure of medical students to the concept of teratogenicity. Multiple exposures on these aspects will help the students in the future to decide the safe drug for a pregnant woman. 


\section{ACKNOWLEDGEMENTS}

Authors would like to thank the students who voluntarily participated in this study.

\section{Funding: No funding sources}

Conflict of interest: None declared

Ethical approval: The study was approved by the Institutional Ethics Committee

\section{REFERENCES}

1. Bisht M, Dhasmana DC. Teratagenecity and Maternogenicity. Myths and Facts. RJPBCS 2014;5(1):452-69.

2. Sharma R. Birth defects in India: Hidden truth, need for urgent attention. Indian $\mathrm{J}$ Hum Genet. 2013;19(2):125-9.

3. Alwan S, Chambers CD. Identifying Human Teratogens: An Update. J Pediatr Genet. 2015;4:3941.

4. World Health Organization. Fact sheet: Congenital anomalies, 2016. Available at: http://www.who.int/mediacentre/factsheets/fs370/en/. Accessed 14 August 2017.

5. National Health Portal. Congenital anomalies (birth defects), 2016. Available at: https://www.nhp.gov.in/disease/gynaecology-andobstetrics/congenital-anomalies-birth-defects. Accessed 14 August 2017.

6. Kar A. Birth Defects in India: Magnitude, Public Health Impact and Prevention. JKIMSU. 2014;3(2):716.

7. Chauhan PR, Mehta RV, Chauhan GR, Chauhan B, Rathi S. A study of Prescription of Potentially Teratogenic Medications to the females of Reproductive age group (14-45 years) in Surendranagar. Int J Biol Med Res. 2012;3(2):1498501.

8. Feldkamp ML, Carey JC, Byrne JL, Krikov S, Botto LD. Etiology and clinical presentation of birth defects: Population based study. BMJ. 2017;357:j2249.

9. Sachdeva P, Patel BG, Patel BK. Drug Use in Pregnancy; a Point to Ponder. Ind J Pharm Sci. 2009 JanFeb;71(1):1-7.
10. Khan AK, Banu G. A questionnaire based survey on knowledge, attitude and practices of medical practitioners regarding the prescribing of medications during pregnancy. Int $\mathrm{J}$ Reprod Contracept Obstet Gynecol. 2016 Apr;5(4):984-8.

11. Kureshee NI, Dhande PP. Awareness of Mothers and Doctors about Drug Utilization Pattern for Illnesses Encountered during Pregnancy. J Clin Diagn Res. 2013;7(11):2470-4.

12. Centers for Disease Control and Prevention. Understanding the Causes of Major Birth Defects: Steps to Prevention, 2015. Available at: https://www.cdc.gov/cdcgrandrounds/pdf/archives/20 15/january2015.pdf. Accessed 14 August 2017.

13. Tamboli TJ, Pundarikaksha HP, Ramaiah M, Bhatt KA, Prasad SR. Impact of educational session on knowledge and attitude towards antimicrobial prescribing and awareness about antimicrobial resistance among undergraduate medical, dental and nursing students: a comparative study. Int J Basic Clin Pharmacol. 2016;5:1544-50.

14. Divyalasya TVS, Vasundara K, Pundarikaksha HP. Impact of educational session on knowledge and attitude toward palliative care among undergraduate medical, nursing and physiotherapy students: a comparative study. Int $\mathbf{J}$ Basic Clin Pharmacol. 2014;3:442-6.

15. Nisar YB, Alam A, Aurangzeb B, Dibley MJ. Perceptions of antenatal iron-folic acid supplements in urban and rural Pakistan:a qualitative study. BMC Pregnancy and Childbirth. 2014;14:344.

16. Wilcock J, Strivens J. A study to enhance medical students' professional decision-making, using teaching interventions on common medications. Medical education online. 2015;20:1.

Cite this article as: Kumari $\mathrm{P}$, Krishnaiah V, Kumaraswamy G, Tamboli TJ. Impact of educational session on knowledge and attitude towards teratogenicity among undergraduate medical students: a comparative study. Int J Basic Clin Pharmacol 2017;6:2642-5. 